\title{
Supplementation of Rice Flour With Carrot, Date Palm and Defatted Soybean Flours for Enhanced Nutritional, Antioxidants and Physicochemical Properties
}

\author{
Olugbenga Olufemi Awolu ${ }^{\star}$ \\ Temitope Esther Olabiran ${ }^{2}$
}

'Department of Food Science and Technology, Federal University of Technology, Akure, Nigeria. Email:OOAWOLU@futa.edu.ng

${ }^{2}$ Central Research Laboratory, Federal University of Technology, Akure, Nigeria.

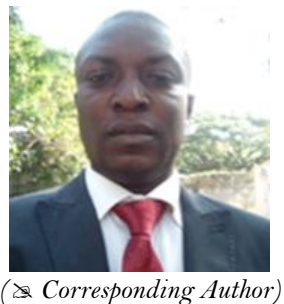

\section{Abstract}

The nutritional, antioxidants and physicochemical properties of rice flour is being improved by the addition of carrot, date palm and defatted soybean flours. The effect of the addition of defatted soy bean $(5-15 \%)$, carrot $(5-15 \%)$ and date palm $(10-20 \%)$ flours on the chemical compositions; antioxidants and functional properties; and pasting characteristics of rice-based composite flour were investigated. While defatted soy beans $(15 \%)$ resulted in the highest protein content $(17.86 \%)$, blend with highest carrot flour inclusion had the highest ash $(1.88 \%)$ and crude fiber (1.93\%) contents. The sample with highest carrot inclusion (15\%) had the best antioxidant and functional properties followed by the sample with soy bean incorporation from 10 to $15 \%$. The same sample with $15 \%$ carrot inclusion had the second best pasting characteristics, next to that of $100 \%$ rice flour sample. It was noted that the samples consisting date palm $(80 \%$ rice and $20 \%$ date palm flours; $80 \%$ rice, $5 \%$ soybean, $5 \%$ carrot and $10 \%$ date palm flours) had the least chemical composition together with the least functional and antioxidant properties. However, the sample with date palm incorporation had the third best pasting properties while $100 \%$ rice flour had the best pasting properties. Overall, carrot flour incorporation resulted in rice based composite flour with the best fibre and minerals contents; functional and antioxidants properties closely followed by sample with 10-15\% soybean incorporation.

Keywords: Antioxidants, Pasting properties, Functional properties, Rice flour, Defatted soya bean flour, Carrot flour, Date palp flour.

Citation | Olugbenga Olufemi Awolu; Temitope Esther Olabiran (2019). Supplementation of Rice Flour With Carrot, Date Palm and Defatted Soybean Flours for Enhanced Nutritional, Antioxidants and Physicochemical Properties. Agriculture and Food Sciences Research, 6(1): 134-144.

History:

Received: 19 March 2019

Revised: 26 April 2019

Accepted: 29 May 2019

Published: 4 July 2019

Licensed: This work is licensed under a Creative Commons

Attribution 3.0 License $(\mathrm{cc})$ )

Publisher: Asian Online Journal Publishing Group
Contribution/Acknowledgement: Both authors contributed to the conception and design of the study.

Funding: This study received no specific financial support.

Competing Interests: The authors declare that they have no conflict of interests.

Transparency: The authors confirm that the manuscript is an honest, accurate, and transparent account of the study was reported; that no vital features of the study have been omitted; and that any discrepancies from the features of the study have been omitted;
study as planned have been explained.

Ethical: This study follows all ethical practices during writing.

\section{Contents}

1. Introduction

2. Material and Methods

(135

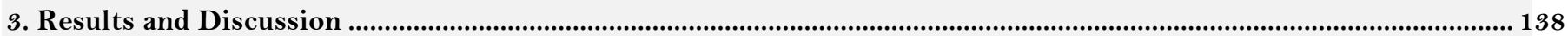

4. Conclusion

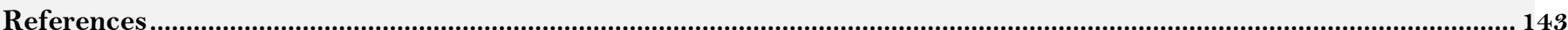




\section{Contribution of this paper to the literature}

This study contributes to the existing knowledge by enhancing utilization of rice flour as an alternative to wheat flour, and also to promote gluten-free flour for baked products production. Vital nutritional compositions of the rice flour such as dietary fibre, protein contents, and bioactive components were enhanced by the incorporation of defatted soybean and carrot flours, while the functional and rheological properties were also enhance by the addition of date palm, carrot and soybean flours.

\section{Introduction}

Researches into viable alternatives to wheat flour in the preparation of baked foods is currently predominant among researchers working on baked food materials. Wheat has proof to be a perfect food materials for preparing baked foods. However, some health challenges in some individuals with gluten intolerance, and economic considerations [1] has led to diversification of researches into viable alternatives to the utilization of wheat as a sole source of raw materials for baked foods. While successes are being recorded in non-wheat baked food materials, there are however, some challenges which has hindered the full utilization of non-wheat materials for baked foods, especially in production of bread. Non-wheat materials are lacking in gluten, which is responsible for the viscoelastic behavior of dough. Present researches are therefore focused on evolving mechanism that will mimic gluten in non-wheat food materials in order to produce non-wheat dough with adequate viscoelastic properties.

Several techniques have been adopted to enhance the rheological characteristics of non-wheat dough, including the use of hydrocolloids, starch, enzymes, other binders and flour modification [1, 2]. It has also been found that incorporation of legumes, dietary fibre and sweeteners into non-wheat flour would enhance the rheological properties [2, 3].

Cereals have been used as a viable alternative to wheat in production of wheat flour [4]. Several cereals and pseudo-cereals including, rice, amaranth grain, maize, tigernut and pearl millet $[5,6]$ had been used as an alternative to wheat. Rice (Oryza sativa) is staple food and a popular cereal worldwide. The rice grain consists about $75-80 \%$ starch, $12 \%$ water and about $7 \%$ protein with a full complement of amino acids. Its protein is highly digestible with excellent biological value and protein efficiency ratio owing to the presence of higher concentration of lysine [7]. Rice flour contains low levels of sodium and a high amount of easily digested carbohydrates, thus, making it desirable in celiac diets [8].

Soybeans (Glycine max) have a great potential as human food because of their high level of good quality protein, unique functional and nutritional properties. Supplementation with soybeans had resulted in baked products with improved nutritional properties, and especially amino acids that are complimentary to most cereals [2, 9]. Soybeans supply all nine essential amino acids and have cholesterol reducing and anticarcinogenic properties [10].

Dates palm (Phoenix dactylifera) is popular in northern Nigeria. It is rich in several vitamins, minerals, dietary fiber but low in calories. Dates provides relief from constipation, intestinal disorders, heart problems, anemia, sexual dysfunction, diarrhea, abdominal cancer, and many other health relating conditions.

Carrot (Daucus carota subsp. sativus) is an important root vegetables rich in bioactive compounds including carotenoids, and dietary fibers; providing appreciable functional characteristics with significant healthpromoting properties. The consumption and usage of carrot and its products is increasing steadily due to its natural antioxidants and anticancer activities $[11,12]$.

This work was conducted to assess the nutritional, functional and pasting properties of rice based composite flour. Soya beans, date palm and carrot flours were added to enhance the nutritional and rheological characteristics of the flour.

\section{Material and Methods \\ 2.1. Materials}

Rice grains, soya beans, date palm and fresh carrots were obtained from Erekesan market, Akure, Ondo State, Nigeria. All reagents used were of analytical grade.

\subsection{Samples Preparation of Rice Flour}

Rice was processed into flour by method described by Awolu, et al. [5]. Rice grains were cleaned, sorted, weighed. The grains were milled using blender (Scanfrost, SFKAB409), cooled and sieved through $150 \mu \mathrm{m}$ mesh size sieve. The flour was later stored in an air tight polyethylene at room temperature.

\subsection{Preparation of Defatted Soya Beans Flour}

Defatted soya bean flour was produced using the method described by Ihekoronye and Ngoddy [13] with slightly modification. Two kilograms of soybean seeds which were manually sorted and cleaned washed with water 3 times, manually dehulled and dried in cabinet dryer at $45^{\circ} \mathrm{C}$. The dried seeds were milled using blender (Scanfrost, SFKAB409) and made to pass through $150 \mu \mathrm{m}$ mesh sieve in order to obtain cooked full-fat soy bean flour. The full-fat soybean flour was defatted using soxhlet extraction with hexane as the solvent. The defatted soy bean flour was packaged in an air tight container for further analysis

\subsection{Preparation of Date Palm Flour}

Date palm flour was prepared according to the method described by Shaba, et al. [14]. Date palm fruits were sorted, cleaned and oven-dried at $40^{\circ} \mathrm{C}$ for $72 \mathrm{~h}$. The dried date palp fruits were milled using household grinder and sieved $(150 \mu \mathrm{m}$ mesh size) to obtained the date palm flour. The flour obtained was stored in an air tight polyethylene pack until use. 


\subsection{Preparation of Carrot Flour}

Carrot flour was prepared according to the method described by Gazalli, et al. [15]. About $1 \mathrm{~kg}$ of carrots were washed with distilled water for cleaning and removal of extraneous materials. The cleaned carrots were peeled manually, cut into slices and ground to paste in home mixer. The paste was spread evenly on trays and dried in an oven at $40 \pm 2^{\circ} \mathrm{C}$. The dried paste was removed from oven when constant weight was attained. Dried carrot was milled in a grinder to form powder; then sieved and stored in air tight food grade plastic containers until used.

\subsection{Proximate Composition}

Proximate composition, including moisture, ash, protein, fat and fiber contents of the flours were determined using AOAC, 2005 methods. The carbohydrate content was determined by difference.

\subsection{Determination of Moisture Content}

The moisture content was determined according to AOAC [16]. A sample of $5 \mathrm{~g}$ was weighed into a known weight of a clean empty Petri dish $\mathrm{W}_{1}$. The weight of the Petri dish and the sample was taken and recorded as $\mathrm{W}_{2}$. The Petri-dish was placed into a preset oven of $105{ }^{\circ} \mathrm{C}$ for $3 \mathrm{~h}$ in order to reduce the moisture. After $3 \mathrm{~h}$, the Petri dish was taken out and placed inside desiccators for about 30 min so that it can cool. After cooling, the sample was brought out and weighed on a weighing balance. The weight was recorded as $\mathrm{W}_{3}$.

$$
\% \text { Moisture Content }=\frac{W_{2}-W_{3}}{W_{1}} \times 100
$$

Where: $\mathrm{W}_{1 .}=$ Weight of empty Petri dish

$\mathrm{W}_{2}=$ Weight of the Petri dish and the sample before moisture removal

$\mathrm{W}_{3}=$ Weight of the Petri dish and sample after the removal of moisture

\subsection{Determination of Fat Content}

The fat content was determined using soxhlet apparatus as described by AOAC [16]. A sample of $5 \mathrm{~g}$ was weighed into a pre-weighed filter paper, weighed, dried in an oven and tied with thread. The filter paper containing the sample was placed in the receiver of the soxhlet apparatus. Normal hexane of boiling point range $60-68^{\circ} \mathrm{C}$ was used as solvent for the extraction; a $500 \mathrm{ml}$ round bottom flask was filled to $3 / 4$ with the solvent. The flask was fitted to the soxhlet apparatus with a reflux condenser and placed in an electro mantle heater. Extraction began as the solvent refluxed several times and continued for $4 \mathrm{~h}$ until the condenser was detached. The filter paper containing the defatted sample was removed and dried to a constant weight in an oven at $50{ }^{\circ} \mathrm{C}$. The difference in weight before extraction and after extraction was recorded in order to obtain the value of the fat extracted.

\subsection{Determination of Ash Content}

$$
\% \text { Fat Content }=\frac{\text { Weight of fat extracted }}{\text { Weight of sample }} \times 100
$$

The Ash content of the sample was determined as described by AOAC [16]. About $2 \mathrm{~g}$ of the sample was weighed in a clean pre-weighed crucible and weight was recorded as $\mathrm{W}_{2}$. The crucible with the sample was placed in a muffle furnace and the temperature was increased to $500{ }^{\circ} \mathrm{C}$ for $3 \mathrm{~h}$ in order to allow the sample to burn (ash). After ashing, the crucible with the ash was cooled in desiccators and then weighed.

$$
\% \text { Ash Content }=\frac{W_{3}-W_{1}}{W_{2}-W_{1}} \times 100
$$

Where:

$\mathrm{W}_{1}=$ weight of empty crucible

$\mathrm{W}_{2}=$ weight of sample and crucible before ashing

$\mathrm{W}_{3}=$ weight of crucible and the ashed sample.

\subsection{Determination of Crude Fibre Content}

Crude fibre was determined as described by AOAC [16]. A defatted sample of about $2 \mathrm{~g}$ was weighed and transferred into a $500 \mathrm{ml}$ conical flask where $200 \mathrm{ml}$ of $1.25 \% \mathrm{H}_{2} \mathrm{SO}_{4}$ was added and the sample were boiled for 30min using cooling fingers to maintain constant temperature. After boiling, the mixture was poured into filter cloth under gentle suction using a butcher funnel, rinsed well with hot distilled water. The material was transferred into a conical flask containing $200 \mathrm{ml}$ of $1.25 \% \mathrm{NaOH}$ and boiled for another 30 min while shaking gently to avoid spillage. The sample solution was filtered, washed with hot distilled water and with $1 \% \mathrm{HCl}$ respectively. The washing was repeated twice with ethanol and trice with petroleum ether to remove any remaining fat. The residue was transferred into a clean dried crucible, oven dried, cooled in the desiccators and weighed $\left(\mathrm{W}_{2}\right)$. The crucible was placed in the muffle furnace at $450{ }^{\circ} \mathrm{C}$ for $2 \mathrm{~h}$, cooled in a desiccators and reweighed $\left(\mathrm{W}_{3}\right)$.

$$
\% \text { Crude fibre }=\frac{\text { Weight of Crude Fibre }}{\text { Weight of sample }} \times 100
$$

\subsection{Determination of Crude Protein Content}

The crude protein was determined using the kjeldahl method. Exactly $0.5 \mathrm{~g}$ of sample was digested using $10 \mathrm{ml}$ of sulphuric acid and $0.5 \mathrm{~g}$ selenium catalyst at $400^{\circ} \mathrm{C}$ for $1 \mathrm{~h}$ until there was a complete digestion which is indicated by a blue green colouration. The flask was allowed to cool after which the digest was diluted with distilled water into a $100 \mathrm{ml}$ standard flask. About $20 \mathrm{ml}$ of $40 \% \mathrm{NaOH}$ solution was added to $10 \mathrm{ml}$ of the digest and three drops of mixed indicator was added to the receiving flask containing $10 \mathrm{ml}$ of $2 \%$ boric acid solution to give a pink colour solution. The sample was distilled until about $50 \mathrm{ml}$ of the distillate was collected 
in the receiving flask. The resulting solution in the conical flask was titrated against $0.1 \mathrm{M} \mathrm{HCl}$ solution until a colour change from green to red wine is obtained indicating the end point. Nitrogen $=\frac{\text { Titre value X Molarity of acid used X } 0.014 \mathrm{X} \text { Dillution factor } \times 100}{\text { Weight of the sample }}$

$\%$ Crude protein $=\%$ Nitrogen $\times 6.25$

\subsection{Determination of Carbohydrate Content}

Carbohydrate content was determined by difference. The summation of protein, fat, moisture content, ash, crude fibre minus 100.

$$
\% \text { carbohydrate }=100-(\text { moisture }+ \text { fat }+ \text { crude fibre }+ \text { ash }+ \text { protein })
$$

\subsection{Determination of Mineral Elements}

Determination of zinc, iron, calcium, magnesium, sodium, potassium and phosphorus were done according to the method of AOAC [16]. The analysis of sodium and potassium were carried out using flame photometer. Calcium, magnesium, iron and zinc were analyzed using Atomic Absorption Spectrometer (Buck Scientific, Model 2 10VGP). Phosphorus was determined by using phosphovanado-molybdate method.

\subsection{Determination of Functional Properties}

The standard analytical procedures [16] for food analysis as described below were used.

\subsection{Bulk Density}

Firstly, a dried and empty measuring cylinder was weighed $\left(\mathrm{W}_{1}\right)$. The sample was filled gently into the weighed measuring cylinder and then gently tapped at the bottom on a laboratory bench several times until there was no further diminution of the sample level, the volume was noted (V). After this, the filled measuring cylinder was weighed and recorded $\left(\mathrm{W}_{2}\right)$. This process was repeated two times. Bulk density was calculated using Equation 7.

$$
\text { Bulk Density }(g / m l)=\frac{W_{2}-W_{1}}{V(m l)}
$$

\subsection{Water/Oil Absorption Capacity}

About $1.0 \mathrm{~g}$ of the ground sample was weighed into a conical graduated centrifuge tube and $10 \mathrm{ml}$ of water or oil was added to the weighed sample. A warring whirl mixer was used to mix the sample for $30 \mathrm{~s}$. The sample was allowed to stand at room temperature for $30 \mathrm{~min}$ and then centrifuged at $5000 \mathrm{rpm}$ for $30 \mathrm{~min}$. The mixed sample was transferred from the graduated centrifuge tube into a $10 \mathrm{~cm}^{3}$ measuring cylinder to know the volume of the free water or oil. The absorption capacity was expressed as grammes of water or oil absorbed per gramme of sample Equation 8.

$$
\text { water /oil absorption capacity }=(\text { total water /oil absorbed }- \text { free water } / \text { oil }) \times \text { density of water } /
$$

$$
\text { oil }
$$

\subsection{Foaming Capacity}

About $2.0 \mathrm{~g}$ of the powdered sample were weighed and blended with $100 \mathrm{~cm}^{3}$ of distilled water using warring blender (Binatone BLG- 555), the suspension was whipped at $1600 \mathrm{rpm}$ for $5 \mathrm{~min}$. The mixture was then poured into a $100 \mathrm{~cm}^{3}$ measuring cylinder and its volume was recorded after $30 \mathrm{~s}$. Foam capacity was expressed as Equation 9.

$$
\text { foaming capacity }=\frac{(\text { volume after whipping-volume before whipping }) \times 100}{\text { volume before whipping }}
$$

\subsection{Least Gelation Capacity}

About $5 \mathrm{~cm}^{3}$ of $2-20 \%(\mathrm{w} / \mathrm{v})$ suspended samples in test tubes were heated for $1 \mathrm{~h}$ in a boiling water bath followed by rapid cooling under running cold tap water. The test tubes were further cooled for $2 \mathrm{~h}$ at $4{ }^{\circ} \mathrm{C}$. The gelation capacity was the least gelation concentration determined as the concentration when the sample from the inverted test tube did not fall or slip.

\subsection{Solubility and Swelling Power}

Well blended sample $(1.0 \mathrm{~g})$ was weighed into a centrifuge tube. About $10 \mathrm{ml}$ of distilled water was added, properly mixed and boiled in a water bath at $80{ }^{\circ} \mathrm{C}$ for $30 \mathrm{~min}$. The tubes were centrifuged at $2200 \mathrm{rpm}$ for $15 \mathrm{~min}$, while the supernatant was decanted into a previously weighed petri dish $\left(\mathrm{W}_{1}\right)$. It was then evaporated and dried in the oven, the dish was re weighed $\left(\mathrm{W}_{2}\right)$. Solubility index was calculated using Equation 10.

$$
\% \text { Solubility }=\frac{\left(w_{2}-w_{1}\right) \times 100}{\text { sample weight }}\left(W_{2}-W_{1}\right) \times 100
$$

The gel or paste from the solubility was weighed and calculated for swelling power Equation 11.

$$
\% \text { swelling power }=\frac{(\text { weight of gel } \times 100)}{\text { sample weight }}
$$

\subsection{Determination of Pasting Properties}

The pasting characteristics of the composite flours were evaluated using Rapid Visco Analyser (RVA). The amount of the sample to be used was determined from the instrument by inserting the moisture content $(14 \%$ in this case). The mixture were vigorously but carefully stirred until there was no more lumps. The solution was carefully transferred into the canister, inserted into the paddle coupling properly. The measurement cycle was initiated by depressing the motor tower of the instrument. The test was then allowed to proceed and terminate 
automatically according to the pre-set time and temperature regime. The pasting properties were recorded at the end of the experiment.

\subsection{Quantification of Antioxidant Properties of the Flour Blends \\ 2.21.1. Sample Extraction for Antioxidant Assay}

Extracts from the samples were prepared using acidified methanol ( $1 \% \mathrm{HCl}$ in methanol). The samples were extracted with $50 \mathrm{ml}$ of solvents in three different phases. About $10 \mathrm{ml}$ solvent was added to $0.5 \mathrm{~g}$ of the sample in a conical flask and completely covered with aluminum foil. The sample was stirred for $4 \mathrm{~h}$ using a shaker, transferred to $40 \mathrm{ml}$ plastic centrifuge tubes, and centrifuged at $3500 \mathrm{rpm}$ for $10 \mathrm{~min}\left(25^{\circ} \mathrm{C}\right)$. it was later decanted and the supernatants were stored in a glass bottle container covered with aluminum foil and kept in the cold room prior to analysis.

\subsection{Determination of Total Phenolic Content}

The total phenolic content was determined by using the method of Waterman and Mole [17]. A tannic acid standard solution of concentration of $0,0.2,0.4,0.6,0.8$ and $1.0 \mathrm{mg} / \mathrm{ml}$ by serial dilution from $1 \mathrm{mg} / \mathrm{ml}$ standard stock solution was prepared. About $0.5 \mathrm{ml}$ of methanolic phenolic acid extract/tannic acid (standard) was added into a $50 \mathrm{~mL}$ volumetric flask containing $10 \mathrm{ml}$ distilled water. Folin-Ciocalteu's phenol reagent (2.5 ml) was added and mixed. After $2 \mathrm{~min}, 7.5 \mathrm{ml}$ of sodium carbonate $\left(\mathrm{NaCO}_{3}\right)$ solution $(20 \mathrm{~g} / 100 \mathrm{~mL})$ was added. The content was mixed and made up to volume with deionized water. The volumetric flask was then stopped and thoroughly mixed by inverting several times while the flask was allowed to stand for $2 \mathrm{~h}$ from the addition of sodium carbonate after which the absorbance was measured at $760 \mathrm{~nm}$ at the different standard solution concentrations.

\subsection{Determination of Total Flavonoid Content}

The total flavonoid content of the extract was determined using a slightly modified method reported by Meda, et al. [18]. About $0.5 \mathrm{ml}$ of appropriately diluted sample was mixed with $0.5 \mathrm{ml}$ methanol, $50 \mu \mathrm{l}$ of $10 \%$ $\mathrm{AlCl}_{3}, 50 \mu \mathrm{l}$ of $1 \mathrm{~mol} \mathrm{l} \mathrm{l}^{-1}$ potassium acetate and $1.4 \mathrm{ml}$ water, and allowed to incubate at room temperature for 30 min. Thereafter, the absorbance of the reaction mixture was subsequently measured at $415 \mathrm{~nm}$. The total flavonoid was calculated using quercetin as standard by using a seven-point standard curve $(0-100 \mu \mathrm{g} / \mathrm{mL})$, the total flavonoids content of samples was determined in triplicates.

\subsection{Determination of 2, 2-Azino-bis (3-Ethylbenzo-Thiazoline-6-Sulfonate (ABTS)) Radical Scavenging-} Ability

The reduced (ABTS) concentration by a certain amount of antioxidant is related to that of trolox, the water-soluble vitamin $\mathrm{E}$ analogue and this gives the Trolox equivalents (TEA) value of the antioxidants Awika, et al. [19]. The working solution $(2.9 \mathrm{ml})$ was added to Trolox standard $(0.1 \mathrm{ml})$ in test tubes and mixed. The test tubes were allowed to react for $30 \mathrm{~min}$ for both Trolox and the samples and the absorbance of the standard and samples was measured at $734 \mathrm{~nm}$. The antioxidant activity was calculated by using Equation 12 .

\footnotetext{
Where $m=$ slope of the standard curve

$\triangle \mathrm{ABS}=$ absorbance of blank-absorbance of sample

$\mathrm{C}=\mathrm{y}$-intercept and $\mathrm{TE}$ is Trolox equivalent.
}

$$
\text { Antioxidant activity }(\mu \mathrm{MTE} / \mathrm{g} \text { Sample })=\frac{\mathrm{m} \times \triangle \mathrm{ATBS}+\mathrm{C}}{\text { Sample }}
$$

\subsection{Determination of Ferric Reducing Antioxidant Property (FRAP)}

The reducing property of the extracts was determined by assessing the ability of the extract to reduce $\mathrm{FeCl}_{3}$ solution as described by Oyaizu [20]. Appropriate dilution of the extract (2.5 ml) was mixed with $2.5 \mathrm{ml}(200$ $\mathrm{mM}$ ) sodium phosphate buffer $(\mathrm{pH} 6.6)$ and $2.5 \mathrm{ml}(1 \%)$ potassium ferricyanide. The mixture was incubated at 50 ${ }^{\circ} \mathrm{C}$ for $20 \mathrm{~min}$ and then $2.5 \mathrm{ml}(10 \%)$ trichloroacetic acid was added. This mixture was centrifuged at $650 \mathrm{rpm}$ for $10 \mathrm{~min}$. Supernatant of about $5 \mathrm{ml}$ was mixed with an equal volume of water and $1 \mathrm{ml}$ of $0.1 \%$ ferric chloride. The absorbance was measured at $700 \mathrm{~nm}$.

\subsection{1,1-Diphenyl-2 Picrylhydrazyl (DPPH) Free Radical Scavenging Ability}

The free radical scavenging ability of the extracts against DPPH (1,1-diphenyl-2 picrylhydrazyl) free radical was evaluated as described by Gyamfi, et al. [21]. Appropriate dilution of the extracts (1 ml) was mixed with $1 \mathrm{ml}$, 0.4 mM methanolic solution containing DPPH radicals, the mixture was left in the dark for $30 \mathrm{~min}$ and the absorbance was taken at $516 \mathrm{~nm}$. The DPPH free radical scavenging ability was subsequently calculated.

\subsection{Statistical Analysis}

The Data for the analysis was generated in triplicate and was subjected to one way Analysis of variance (ANOVA), SPSS 19.00 while means was separated using Duncan multiple range test (DMRT) at $p<0.05$

\section{Results and Discussion \\ 3.1. Proximate Compositions of the Flours}

The proximate compositions of the rice based flour blend are presented in Table 1. The moisture content value ranged between 4.31 and $7.23 \%$. The flour blends generally had low moisture content which implied that the samples could have an extended shelf life. The reduction in the moisture content can be as a result of extensive drying during processing of the flours. 
There are significant $(\mathrm{p} \leq 0.05)$ differences in the ash contents of the samples; the ash content ranged between 0.71 and $1.88 \mathrm{~g} / 100 \mathrm{~g}$. Carrot and soybean flours addition had the highest positive effect on the ash content. It may however affirm that, while the duo of carrot and soybean flours contributes to the minerals contents, carrot flour seemed to have greater input into the ash contents as could be deduced from sample 2 with $15 \%$ carrot flour and $5 \%$ soybean flour (with highest ash content) in contrast to sample 3 with $5 \%$ carrot flour and $15 \%$ soybean flour coming second behind sample 2 in ash content.

\begin{tabular}{|c|c|c|c|c|c|c|}
\hline Samples & $\begin{array}{l}\text { Moisture } \\
\text { (g/100g) }\end{array}$ & $\begin{array}{c}\text { Ash } \\
(\mathrm{g} / \mathrm{100g}) \\
\end{array}$ & $\begin{array}{c}\text { Protein } \\
(\mathrm{g} / 100 \mathrm{~g})\end{array}$ & $\begin{array}{c}\text { Fat } \\
(\mathrm{g} / \mathrm{100g})\end{array}$ & $\begin{array}{c}\text { Fibre } \\
(\mathrm{g} / 100 \mathrm{~g})\end{array}$ & $\begin{array}{c}\text { CHO } \\
(g / 100 g) \\
\end{array}$ \\
\hline 1 & $4.31 \pm 0.015^{\mathrm{f}}$ & $0.71 \pm 0.000^{f}$ & $11.04 \pm 0.030^{f}$ & $0.54 \pm 0.025^{\mathrm{e}}$ & $0.24 \pm 0.006^{\mathrm{f}}$ & $82.83 \pm 0.015^{\mathrm{a}}$ \\
\hline 2 & $6.51 \pm 0.005^{\mathrm{b}}$ & $1.88 \pm 0.010^{\mathrm{a}}$ & $13.25 \pm 0.000^{\mathrm{d}}$ & $0.58 \pm 0.000^{\mathrm{d}}$ & $1.93 \pm 0.010^{\mathrm{a}}$ & $75.89 \pm 0.006^{\mathrm{d}}$ \\
\hline 3 & $6.01 \pm 0.005^{\mathrm{e}}$ & $1.45 \pm 0.015^{\mathrm{b}}$ & $17.86 \pm 0.075^{\mathrm{a}}$ & $0.68 \pm 0.010^{b}$ & $1.15 \pm 0.010^{\mathrm{c}}$ & $74.65 \pm 0.080^{\mathrm{e}}$ \\
\hline 4 & $7.23 \pm 0.010^{\mathrm{a}}$ & $0.83 \pm 0.000^{\mathrm{e}}$ & $11.35 \pm 0.010^{\mathrm{e}}$ & $0.83 \pm 0.000^{\mathrm{a}}$ & $0.52 \pm 0.005^{\mathrm{e}}$ & $79.50 \pm 0.025^{\mathrm{b}}$ \\
\hline 5 & $6.46 \pm 0.025^{\mathrm{c}}$ & $1.37 \pm 0.010^{\mathrm{c}}$ & $15.94 \pm 0.035^{\mathrm{b}}$ & $0.61 \pm 0.015^{\mathrm{c}}$ & $1.48 \pm 0.020^{\mathrm{b}}$ & $74.00 \pm 0.055^{\mathrm{f}}$ \\
\hline 6 & $6.36 \pm 0.015^{\mathrm{d}}$ & $0.86 \pm 0.025^{\mathrm{d}}$ & $13.60 \pm 0.015^{\mathrm{c}}$ & $0.68 \pm 0.010^{b}$ & $0.82 \pm 0.005^{\mathrm{d}}$ & $77.55 \pm 0.056^{\mathrm{c}}$ \\
\hline
\end{tabular}

Note: Mean \pm Standard deviation of three triplicates. Mean values of the same sample on the same column with the different superscript are significantly different $(\mathrm{p}<0.05)$

Keys:

Keys: $100 \%$ rice flour,

2: $80 \%$ rice flour, $5 \%$ defatted soya beans flour and $15 \%$ carrot flour

3: $80 \%$ rice flour, $15 \%$ defatted soya beans flour and $5 \%$ carrot flour.

4: $80 \%$ rice flour and $20 \%$ date palm flour,

5: $80 \%$ rice flour, $10 \%$ defatted soya beans flour and $10 \%$ carrot flour

6: $80 \%$ rice flour, $5 \%$ defatted soya beans flour, $5 \%$ carrot flour and $10 \%$ date palm flour.

Rice flour alone had the least ash content, while inclusion of only date palm flour alone had $2^{\text {nd }}$ to the last ash content.

The crude fat content ranged between 0.54 and $0.83 \mathrm{~g} / 100 \mathrm{~g}$. Date palm flour inclusion increased the fat contents of the sample. Sample 4 (with $20 \%$ date palm flour) had the highest fat content, followed sample 6 (with $10 \%$ date palm flour). Sample with $15 \%$ soybean flour inclusion (sample 3) also had second highest fat content. These results clearly showed that inclusion of date palm and soybean flours to the samples had positive impact of their fat contents. However, carrot flour inclusion did not contribute strongly to the fat contents. Dietary fat provides essential fatty acids which enhanced the taste and acceptability of foods, slowed gastric emptying and intestinal motility thereby prolonging satiety and facilitating the absorption of liquid soluble vitamins [22].

The crude fibre content increased with increased level of carrot flour. The control (100\% rice flour) had the least crude fibre content $(0.24 \mathrm{~g} / 100 \mathrm{~g})$. Carrots have been reported to contain high dietary fibers [23] dietary fibers play an important role in human health [24]. Dietary fiber is important for the removal of waste from the body thereby preventing constipation and many health disorders.

The protein content of the flours varies considerably with the addition of soybean, carrot and date palm flours. Sample 3 ( $80 \%$ rice, $15 \%$ defatted soya bean and $5 \%$ carrot flour) had the highest protein values of $17.86 \%$ while the control (100\% rice flour) had the least value of $11.35 \%$. The contribution of defatted soya beans to protein is very high and this justifies the addition of soya beans which was intended to increase the protein content of the flour. Samples 5 and 6, with second and third best protein contents respectively, showed that incorporation of carrot flour also contributed to the protein contents of the composite flour. The same trend were not reported in composite flour with only date palm flour (sample 4) with protein content almost equal to that of $100 \%$ rice flour.

The carbohydrate content of the composite flours were reduced with the incorporation of soybean, carrot and date palm flours. Control sample had the highest value of $82.83 \%$ while sample 5 ( $80 \%$ rice flour, $10 \%$ defatted soya beans flour and $10 \%$ carrot flour) had the least value of $72.07 \%$. This might not be unconnected with the high protein contents in both soybean and carrot flours which resulted in high protein content of sample 5, and hence, a lower carbohydrate content.

\subsection{Minerals Composition of the Flours}

The mineral compositions of the composite flour are presented in Table 2. Sample 5 ( $80 \%$ rice flour, $10 \%$ defatted soya beans flour and $10 \%$ carrot flour) was the richest in terms of minerals composition, followed by sample $2(80 \%$ rice flour, $5 \%$ defatted soya beans flour and $15 \%$ carrot flour), and then sample 4 ( $80 \%$ rice flour and $20 \%$ date palm flour). It could be deduced that soybean and carrot flours contribute most to minerals composition (as reflected in samples 5 and 2). A substantial addition of date palm flour (at about $20 \%$ ) came third in terms of its contribution to overall minerals composition of the composite flour. The sodium content ranged between 97.69 and $189.98 \mathrm{mg} / 100 \mathrm{~g}$. The sodium content increased with the addition of defatted soya beans, carrot and date palm flours. The highest value of sodium $(189.98 \mathrm{mg} / \mathrm{kg})$ was observed in the flour blend that has rice, defatted soya beans and carrot in 80:10:10 respectively. Composite flour sample with lower soybean but higher carrot content (sample 2) had the best potassium content. Increasing $\mathrm{K}$ intake is associated with lowering of blood pressure and the effects of increasing $\mathrm{K}$ intake are additive to the effects of lowering Na intake [25].

It is however noted that all the samples had lower $\mathrm{Na}$ to higher $\mathrm{K}$ contents ratio, which suggest that the samples would serve as appropriate meals for patients with high blood pressure.

Carrot and soybean flours are veritable sources of calcium as samples containing about 20\% (total composition of soybean and carrot flours) had calcium contents between 160 and $192 \mathrm{mg} / 100 \mathrm{~g}$. Calcium, however, showed a better contribution to the calcium content as the sample with $10 \%$ carrot flour incorporation had the highest calcium content; sample with $15 \%$ soybean flour incorporation had lower calcium content compared to the sample with $10 \%$ carrot content. Rice flour $(100 \%)$ had $116.50 \mathrm{mg} / 100 \mathrm{~g}$ calcium content. The least value $(83.74 \mathrm{mg} / 100 \mathrm{~g})$ was observed in sample $4(80 \%$ rice flour and $20 \%$ date palm flour). Calcium is 
needed for bone formation while zinc is essential for protein and nucleic acid synthesis, carbohydrate metabolism, successful pregnancy, delivery and normal development [26].

Table-2. Mineral composition $(\mathrm{mg} / \mathrm{lo0g}$ ) of rice flour and flour blends.

\begin{tabular}{c|c|c|c|c|c|c|c}
\hline Sample & $\mathbf{N a}$ & $\mathbf{K}$ & $\mathbf{C a}$ & $\mathbf{P}$ & $\mathbf{M g}$ & $\mathbf{Z n}$ & $\mathbf{F e}$ \\
\hline 1 & $97.87 \pm 0.015^{\mathrm{f}}$ & $392.93 \pm 0.005^{\mathrm{f}}$ & $116.50 \pm 0.000^{\mathrm{d}}$ & $9.55 \pm 0.015^{\mathrm{f}}$ & $151.25 \pm 0.265^{\mathrm{f}}$ & $10.81 \pm 0.005^{\mathrm{f}}$ & $11.78 \pm 0.015^{\mathrm{f}}$ \\
\hline 2 & $182.8 \pm 0.060^{\mathrm{d}}$ & $1383.80 \pm 0.015^{\mathrm{a}}$ & $174.77 \pm 0.071^{\mathrm{b}}$ & $15.75 \pm 0.020^{\mathrm{c}}$ & $194.30 \pm 0.056^{\mathrm{c}}$ & $13.11 \pm 0.015^{\mathrm{e}}$ & $21.11 \pm 0.015^{\mathrm{a}}$ \\
\hline 3 & $186.7 \pm 0.000^{\mathrm{c}}$ & $1080.40 \pm 0.006^{\mathrm{c}}$ & $160.58 \pm 0.508^{\mathrm{c}}$ & $17.70 \pm 0.020^{\mathrm{a}}$ & $174.05 \pm 0.017^{\mathrm{d}}$ & $13.81 \pm 0.005^{\mathrm{c}}$ & $16.81 \pm 0.005^{\mathrm{c}}$ \\
\hline 4 & $117.69 \pm 0.020^{\mathrm{e}}$ & $710.41 \pm 0.020^{\mathrm{e}}$ & $83.74 \pm 0.006^{\mathrm{f}}$ & $11.25 \pm 0.020^{\mathrm{e}}$ & $226.42 \pm 0.011^{\mathrm{a}}$ & $15.33 \pm 0.000^{\mathrm{a}}$ & $12.55 \pm 0.000^{\mathrm{e}}$ \\
\hline 5 & $189.98 \pm 0.015^{\mathrm{a}}$ & $1364.50 \pm 0.015^{\mathrm{b}}$ & $192.01 \pm 0.015^{\mathrm{a}}$ & $16.35 \pm 0.000^{\mathrm{b}}$ & $187.40 \pm 0.015^{\mathrm{e}}$ & $13.61 \pm 0.005^{\mathrm{d}}$ & $20.39 \pm 0.005^{\mathrm{b}}$ \\
\hline 6 & $159.98 \pm 0.000^{\mathrm{b}}$ & $928.52 \pm 0.015^{\mathrm{d}}$ & $101.12 \pm 0.115^{\mathrm{e}}$ & $11.64 \pm 0.020^{\mathrm{d}}$ & $207.06 \pm 0.000^{\mathrm{b}}$ & $16.28 \pm 0.005^{\mathrm{b}}$ & $13.00 \pm 0.000^{\mathrm{d}}$ \\
\hline
\end{tabular}

Note: Values represent means of triplicate $(\mathrm{n}=3)$. Values with the same alphabet along the same column are not significantly different $(\mathrm{p}>0.05)$.

Keys:

1: $100 \%$ rice flour,

2: $80 \%$ rice flour, $5 \%$ defatted soya beans flour and $15 \%$ carrot flour

3: $80 \%$ rice flour, $15 \%$ defatted soya beans flour and $5 \%$ carrot flour

4: $80 \%$ rice flour and $20 \%$ date palm flour,

5: $80 \%$ rice flour, $10 \%$ defatted soya beans flour and $10 \%$ carrot flour

6: $80 \%$ rice flour, $5 \%$ defatted soya beans flour, $5 \%$ carrot flour and $10 \%$ date palm flour.

Soybean flour showed the best contribution to phosphorus content of the composite flour, followed by carrot flour (samples 3, 5 and 2 in that order). Date palm flour contribution also came a distant fourth position to samples 3,5 and 2 . The phosphorus content of rice $(100 \%)$ was the least.

The results of magnesium and zinc Table 2 indicated that date palm is a good source of both. The higher the incorporation of date palm flour to the composite flour, the higher the values of magnesium and zinc. Magnesium is required for lowering blood pressure [27]. Taking magnesium supplements has been shown to significantly reduced fasting blood sugar levels in participants with type 2 diabetes [28]. On the other hand, Zinc is required by human body to activate $\mathrm{T}$ lymphocytes ( $\mathrm{T}$ cells). $\mathrm{T}$ cells help the body in controlling and regulating immune responses and attacking infected or cancerous cells [29].

Carrot also had positive effect on iron content of the composite flour, as the higher the carrot flour incorporation, the higher the iron content of the composite flour. Iron is an important component of blood and enzymes involved in electron transfer. Its deficiency results in fatigue, headache and sore tongue in addition to anaemia.

The overall results indicated that $100 \%$ rice flour had the least minerals composition. This showed that rice flour needs to be supplemented with minerals rich food materials in order to it nutritionally beneficial.

\subsection{Antioxidants Properties of the Flour Blends}

The presence of protein, fibre and minerals contents only in food is no longer attractive indices for consumers' acceptance of the food. This is as a result of the widespread degenerative diseases confronting humanity, and which had not been successfully controlled with the knowledge of medical and pharmaceutical sciences. Consumption of food rich in antioxidant is being propounded as possible mitigation and cure for these diseases. Food rich in antioxidant have been found to be adequate in the maintenance of health and protection from coronary heart diseases and cancer [30]. The antioxidant properties of the composite flour consisting rice, carrot and soybean flours are presented in Table 3. The addition of carrot and soybean flours in the composite flour resulted in composite flours with greatly enhanced antioxidant properties as observed in samples $2,3,5$ and 6. Date palm flour addition only resulted in the best FRAP (sample 4). The sample with 100\% rice sample had the least antioxidant values. This is an evident that nutritional capacity of rice flour which is currently consumed throughout the world, and especially, in several Asia countries, needs to be enhanced as established in this study in order to properly serve as nutritious food.

\begin{tabular}{c|c|c|c|c|c}
\hline \multicolumn{7}{|c}{ Table-3. Antioxidants in flour blends. } \\
\hline SAMPLES & FRAP mg/g & ABTS mM/g & DPPH \% & TPC mg/g & TFC mg/g \\
\hline 1 & $7.06 \pm 0.040^{\mathrm{f}}$ & $0.018 \pm 0.000^{\mathrm{d}}$ & $77.40 \pm 0.400^{\mathrm{e}}$ & $0.09 \pm 0.005^{\mathrm{f}}$ & $0.06 \pm 0.008^{\mathrm{cd}}$ \\
\hline 2 & $21.36 \pm 0.225^{\mathrm{c}}$ & $0.010 \pm 0.001^{\mathrm{b}}$ & $83.50 \pm 0.000^{\mathrm{c}}$ & $4.59 \pm 0.015^{\mathrm{a}}$ & $0.15 \pm 0.013^{\mathrm{a}}$ \\
\hline 3 & $16.27 \pm 0.040^{\mathrm{e}}$ & $0.02 \pm 0.000^{\mathrm{b}}$ & $89.55 \pm 0.150^{\mathrm{a}}$ & $4.53 \pm 0.004^{\mathrm{b}}$ & $0.13 \pm 0.000^{\mathrm{ab}}$ \\
\hline 4 & $54.28 \pm 0.010^{\mathrm{a}}$ & $0.019 \pm 0.001^{\mathrm{c}}$ & $76.25 \pm 0.250^{\mathrm{f}}$ & $4.49 \pm 0.005^{\mathrm{d}}$ & $0.03 \pm 0.004^{\mathrm{d}}$ \\
\hline 5 & $18.24 \pm 0.085^{\mathrm{d}}$ & $0.03 \pm 0.000^{\mathrm{a}}$ & $85.07 \pm 0.040^{\mathrm{b}}$ & $4.51 \pm 0.000^{\mathrm{c}}$ & $0.10 \pm 0.057^{\mathrm{abc}}$ \\
\hline 6 & $50.06 \pm 0.345^{\mathrm{b}}$ & $0.02 \pm 0.000^{\mathrm{b}}$ & $80.35 \pm 0.075^{\mathrm{d}}$ & $4.09 \pm 0.004^{\mathrm{e}}$ & $0.09 \pm 0.000^{\mathrm{bc}}$ \\
\hline
\end{tabular}

Note: Results are expressed as mean \pm standard deviations (SD) of three determinations. Averages followed by different letters in the

same column differ by Tukey's test at $\mathrm{p}<0.01$.

Keys:

1: $100 \%$ rice flour

2: $80 \%$ rice flour, $5 \%$ defatted soya beans flour and $15 \%$ carrot flour

3: $80 \%$ rice flour, $15 \%$ defatted soya beans flour and $5 \%$ carrot flour,

4: $80 \%$ rice flour and $20 \%$ date palm flour,

5: $80 \%$ rice flour, $10 \%$ defatted soya beans flour and $10 \%$ carrot flour

6: $80 \%$ rice flour, $5 \%$ defatted soya beans flour, $5 \%$ carrot flour and $10 \%$ date palm flour

Phenols are used as an important indicator of antioxidant capacity as well as a preliminary screen for any product that is intended to be used as a natural source of antioxidants in functional foods [31]. There were significant $(\mathrm{p} \leq 0.05)$ differences in the phenolic content of the flour blends. Carrot flour contributes more to the increase in the phenol content of the flour blend followed by defatted soya beans flour and date palm flour. Carrot is a significant source of phytonutrients including phenolic [32] polyacetylenes [33, 34] and carotenoids [35]. The flour blends can serve as a good source of phenolic content.

ABTS assay has been shown to be more sensitive to identifying the antioxidant activity since it has faster reaction kinetics and a heightened response to antioxidants [36]. 
Reducing power is a measure of the ability of the food extracts to reduce $\mathrm{Fe}^{3+}$ to $\mathrm{Fe}^{2+}$. Substances which have reduction potential react with potassium ferric-cyanide to form potassium ferrocyanide which then reacts with ferric chloride to form ferric ferrous complex that has an absorption maximum at 70onm. Reducing power has become one of the antioxidant capacity indicator of medicinal plants [37]. The ferrous Reducing antioxidants property of the flour blends ranged between 7.02 to $54.28 \mathrm{mg} / \mathrm{g}$. Significant differences were observed among all the flour samples. Sample 4, consisting rice and date palm flour (in ratios 80:20, respectively) had the highest FRAP content of $54.28 \mathrm{mg} / \mathrm{g}$. Though defatted soy bean and carrot flours increased the FRAP content of the flour blends, it is observed that date palm increased it better. Several researches have established that dates are rich in FRAP [38]. This might explain the significant increase in the FRAP content of rice flour when supplemented with date palm flour.

The flavonoid content followed the same pattern as the phenolic content. Carrot flour was responsible for the increase in the flavonoid content of the flour blends. A range of 4.50-7.42 $\mathrm{mg} / 100 \mathrm{~g}$ total flavonoids had been reported in raw and processed carrot. Flavonoids are important due to their anti-oxidative, anti-inflammatory, anti-mutagenic and anti-carcinogenic properties coupled with their capacity to modulate key cellular enzyme function. Research on flavonoids received an added impulse with the discovery of the low cardiovascular mortality rate [39].

The DPPH content of the composite flour indicated that soybean flour addition resulted in the highest increase of the DPPH. In addition to soybean addition, carrot flour addition also Defatted soya beans and carrot flour are responsible for the increase in the DPPH content. DPPH assay is used to predict antioxidant activities by mechanism in which antioxidants act to inhibit lipid oxidation, so scavenging of DPPH radical and therefore determinate free radical scavenging capacity [40].

\subsection{Functional Properties of the Flour Blends}

The functional properties of the flour blends are presented in Table 4. As observed in the previous analyses, samples with carrot and soybean flours incorporation had the best functional properties. In this case, sample 5 ( $80 \%$ rice flour, $10 \%$ defatted soya beans flour and $10 \%$ carrot flour) had the best WAC and, second best OAC and SC. Sample 2 (80\% rice flour, $5 \%$ defatted soya beans flour and $15 \%$ carrot flour) had the best OAC and SC. The sample with only date palm flour incorporation to rice flour ( $80 \%$ rice flour and $20 \%$ date palm flour) had the least WAC, OAC and SC. Sample 4 only increased the bulkiness of the composite flour. A WAC of $140 \%$ had been reported for $100 \%$ wheat flour by [41] at the same time, incorporation of rice flour into wheat flour reduced the WAC of the composite flour. Reduction in WAC in composite flours had been attributed to the less availability of polar amino acids in the flours [42] while more availability of hydrophilic constituents (polysaccharides) resulted in flours with high water absorption [41]. The decrease in WAC with incorporation of datepalm flour agrees with the work of [43] who reported that high fibre and starch contents resulted in high water binding capacity. Similarly, Mbofung, et al. [44] reported that the ability of flour to absorb water had a significant correlation with its starch content. WAC is essential in bulking and consistency of products, as well as in baking application [45].

The OAC of wheat flour was reported to be $146 \%$ [41]. Sample 5 had the same OAC as wheat flour Table 4, while the OAC of sample 2 was $155.33 \%$. Samples 2 and 5 , therefore, had OAC around that of $100 \%$ wheat flour. Other samples aside 2 and 5, had OAC significantly ( $\mathrm{p} \leq 0.05$ ) lower than 146\%. The OAC of rice flour was $123.57 \%$, and, samples 4 and 6 with date palm inclusion had very low OAC. Presence of high fat had been reported to adversely affect OAC, while food with high OAC are better for flavour retention, improve palatability, and enhanced shelf life [41, 46].

Swelling capacity (SC) is the ability of a sample to absorb water undisturbed under a room temperature. The swelling power shows the degree of the water absorption of the starch granules in the flour [47]. Supplementation of the composite flour with carrot and soy bean flours resulted in high swelling capacity whereas samples with date palm flours had lower swelling capacity than rice flour.

The sample with date palm flour incorporation had the best solubility power. Sample 4 (80\% rice flour and $20 \%$ date palm) had the highest solubility power of $13.10 \%$ while the control sample, rice flour, had the least value of $1.60 \%$.

Samples 2 and 4 also had foaming capacities similar to $12.92 \%$ reported for $100 \%$ wheat flour by Chandra, et al. [41]. Increase in the protein content (as demonstrated by the increase in soybean content of some of the samples from 5 to $15 \%$ ) could be responsible for increasing foaming capacity.

Table-4. Functional properties of rice flour and flour blends

\begin{tabular}{c|c|c|c|c|c|c|c}
\hline S/N & BD g/ml & WAC \% & OAC \% & Sol \% & SC \% & FC \% & LG \% \\
\hline 1 & $1.03 \pm 0.000^{\mathrm{b}}$ & $78.34 \pm 0.390^{\mathrm{d}}$ & $123.57 \pm 0.00^{\mathrm{d}}$ & $1.60 \pm 0.000^{\mathrm{e}}$ & $259.83 \pm 0.046^{\mathrm{d}}$ & $5.64 \pm 0.073^{\mathrm{f}}$ & $2.00 \pm 0.000$ \\
\hline 2 & $0.66 \pm 0.000^{\mathrm{f}}$ & $86.67 \pm 0.000^{\mathrm{c}}$ & $155.33 \pm 0.680^{\mathrm{a}}$ & $7.60 \pm 0.000^{\mathrm{c}}$ & $294.00 \pm 0.000^{\mathrm{a}}$ & $12.96 \pm 0.000^{\mathrm{d}}$ & $2.00 \pm 0.000$ \\
\hline 3 & $0.91 \pm 0.095^{\mathrm{c}}$ & $89.57 \pm 0.045^{\mathrm{b}}$ & $131.88 \pm 0.010^{\mathrm{c}}$ & $6.50 \pm 0.000^{\mathrm{d}}$ & $262.00 \pm 0.000^{\mathrm{c}}$ & $18.12 \pm 0.051^{\mathrm{c}}$ & $2.00 \pm 0.000$ \\
\hline 4 & $1.21 \pm 0.006^{\mathrm{a}}$ & $71.76 \pm 0.255^{\mathrm{f}}$ & $100.29 \pm 0.005^{\mathrm{f}}$ & $13.10 \pm 0.000^{\mathrm{a}}$ & $234.80 \pm 0.000^{\mathrm{f}}$ & $11.37 \pm 0.045^{\mathrm{e}}$ & $2.00 \pm 0.000$ \\
\hline 5 & $0.73 \pm 0.000^{\mathrm{e}}$ & $101.45 \pm 0.000^{\mathrm{a}}$ & $146.32 \pm 0.165^{\mathrm{b}}$ & $7.80 \pm 0.000^{\mathrm{c}}$ & $274.20 \pm 0.000^{\mathrm{b}}$ & $20.35 \pm 0.020^{\mathrm{b}}$ & $2.00 \pm 0.000$ \\
\hline 6 & $0.80 \pm 0.000^{\mathrm{d}}$ & $76.59 \pm 0.100^{\mathrm{e}}$ & $112.86 \pm 0.030^{\mathrm{e}}$ & $11.20 \pm 0.000^{\mathrm{b}}$ & $244.20 \pm 0.000^{\mathrm{e}}$ & $29.62 \pm 0.005^{\mathrm{a}}$ & $2.00 \pm 0.000$ \\
\hline
\end{tabular}

Note: Values represent means of triplicate $(\mathrm{n}=3)$. Values with the same alphabet along the same column are not significantly different ( $\mathrm{p}>0.05)$

Keys:

1: $100 \%$ rice flour; $\mathbf{2}: 80 \%$ rice flour, $5 \%$ defatted soya beans flour and $15 \%$ carrot flour

3: $80 \%$ rice flour, $15 \%$ defatted soya beans flour and $5 \%$ carrot flour; 4: $80 \%$ rice flour and $20 \%$ date palm flour,

5: $80 \%$ rice flour, $10 \%$ defatted soya beans flour and $10 \%$ carrot flour

6: $80 \%$ rice flour, $5 \%$ defatted soya beans flour, $5 \%$ carrot flour and $10 \%$ date palm flour

BD: Bulk density, WAC: Water absorption capacity, OAC: Oil absorption capacity, Sol: Solubility, SC: Swelling capacity, FC: Foaming capacity, LG: Least gelation.

While sample 4 with $20 \%$ date palm flour incorporation had considerable foaming capacity, the combination of date palm with soybean had astronomically increased the foaming capacity of the sample. The control sample has the least foaming capacity of $5.64 \%$. 
There was no significant $(\mathrm{p}>0.05)$ difference in least gelation capacity of the flour blends. All the composite flour samples gelled at $2 \%$. A least gelation capacity (LGC) of $8 \%$ was reported for $100 \%$ wheat flour [41]. LGC was defined as the lowest protein concentration at which gel remained in the inverted tube. Samples with a lower LGC has been shown to have better protein gelling ability [48] and also enhance the swelling capacity of the sample [42]. It can be therefore inferred that the samples all had good LGC (the values are lower than values reported for $100 \%$ wheat flour).

The bulk density of flour is the density measured without the influence of any compression [41]. A bulk density of $0.762 \mathrm{~g} / \mathrm{cc}$ was reported for $100 \%$ wheat flour according to Chandra et al. (2015). The samples with $\mathrm{BD}$ closest to that of $100 \%$ wheat flour are samples $5(-0.03)$, sample $6(+0.04)$, sample $2(-0.10)$ and sample 3 $(+0.14)$ in that order. On the other hand, samples $1(100 \%$ rice flour $)$ and $4(80 \%$ rice flour and $20 \%$ date palm flour) had the highest BD. Flour samples with high BD are good as thickeners, while those with lower BD are better for complementary foods.

\subsection{Pasting Property of the Flour Blends}

The pasting property of the flour blends is presented in Table 5 . There was significant $(\mathrm{p} \leq 0.05)$ difference in the pasting temperature of the flour blends. The pasting temperature is an indication of the minimum temperature required to cook or gelatinize the flour [49]. In general, sample 4 and 5 had the highest and same pasting temperature of $92.05{ }^{\circ} \mathrm{C}$. The control sample has the least pasting temperature of $88.75{ }^{\circ} \mathrm{C}$. Pasting temperature is the temperature at which the first detectable increase in viscosity is measured and it is an index characterized by the initial change due to the swelling of starch [50].

Table-5.Pasting property of rice flour and the flour blends.

\begin{tabular}{c|c|c|c|c|c|c|c}
\hline Sample & PV Cp & T cP & BD Cp & FV Cp & SB cP & PAT Min & PT $^{\circ} \mathbf{c}$ \\
\hline 1 & 2543.00 & 2145.00 & 398.00 & 4025.00 & 1880.00 & 5.93 & 88.75 \\
\hline 2 & 1520.00 & 1429.00 & 91.00 & 2622.00 & 1193.00 & 6.13 & 90.45 \\
\hline 3 & 1186.00 & 1155.00 & 31.00 & 2261.00 & 1106.00 & 6.87 & 91.20 \\
\hline 4 & 1249.00 & 1192.00 & 57.00 & 2261.00 & 1069.00 & 6.20 & 92.05 \\
\hline 5 & 1282.00 & 1249.00 & 33.00 & 2374.00 & 1125.00 & 6.40 & 91.30 \\
\hline 6 & 1312.00 & 1250.00 & 62.00 & 2354.00 & 1104.00 & 6.33 & 92.05 \\
\hline Keys:
\end{tabular}

Keys:

1: $100 \%$ rice flour,

2: $80 \%$ rice flour, $5 \%$ defatted soya beans flour and $15 \%$ carrot flour

3: $80 \%$ rice flour, $15 \%$ defatted soya beans flour and $5 \%$ carrot flour,

4: $80 \%$ rice flour and $20 \%$ date palm flour,

5: $80 \%$ rice flour, $10 \%$ defatted soya beans flour and $10 \%$ carrot flour

5: $80 \%$ rice flour, $10 \%$ defatted soya beans flour and $10 \%$ carrot flour

PV; Pasting viscosity, T: Trough, BD: Breakdown, FV: Final viscosity, SB: Setback, PAT: Pasting time, PT: Pasting temperature

The results of the pasting characteristics indicate that the higher level of defatted soybean flour, carrot flour and date palm flour reduced the peak viscosity (PV), trough (T), break down viscosity (BD), final viscosity (FV), and setback viscosity (SB) of composite flour. This is due to the existence and interaction of components like fat and protein from soybean flour with carrot flour and date palm flour that decrease the viscosity [51]. In general, the viscosity of composite flour was lower than rice flour.

The PV of composite flours ranged from $1186.00 \mathrm{cP}$ to $2543 \mathrm{cP}$. It was found that the peak viscosity decreased as defatted soybean flour supplementation increased, but the ratio of carrot and date palm flours only had little effect on peak viscosity of composite flours. Awolu, 2018 reported 3290.50 RVU - 5232.50 RVU for optimized based flour. The differences in the starch and protein composition in the flours could affect pasting viscosity and properties [52,53]. The peak viscosity attained during the heating portion of tests indicates the water binding capacity of starch mixture. This often correlates with final product qualities [54] found that starch from yam (Dioscorea alata) varieties with higher peak viscosities produced pounded yam with good textural quality whereas the $D$. alata varieties, with lower peak viscosities, did not give pounded yam of the acceptable textural quality.

Breakdown measures the ease with which the swollen granules can be disintegrated [49]. The break down ranged between $31.00 \mathrm{cP}$ and $398.00 \mathrm{cP}$. The lower breakdowns (BD) were found in composite flours, as compared with the rice flour. The breakdown viscosity also decreases as soybean flour level increases in composite flour.

The final viscosity (FV) indicated the re-association of starch granules especially amylose during cooling time after gelatinization and the formation of gel network [55]. The final viscosity ranged between $2261.00 \mathrm{cP}$ and $4025 \mathrm{cP}$.

Setback value has been reported to correlate with ability of starches to gel into semi solid paste. The setback value ranged between 1104.00 to $1880.00 \mathrm{cP}$. The control sample had the highest set back of $1880.00 \mathrm{cP}$. The lower setback viscosity was observed in samples 3 and 6 and it can be associated with increase in soybean flour level. Lower set back is an indication of starch stability [3].

Also the peak time ranged between $5.93 \mathrm{mins}$ to $6.87 \mathrm{mins}$. The control sample had the least peak time of 5.93 while the flour that was complemented with much defatted soya beans had the highest peak time of $6.87 \mathrm{mins}$. It is observed that soya beans is responsible for the increase in the peak time.

\section{Conclusion}

This present study showed that all the flour blends exhibited potent antioxidant property and increased the nutritional and functional quality of the flour, but amongst all, carrot exhibited the highest potency. This study has shown that nutritious gluten free flour can be produced from blends of local products such as rice, soya beans, carrot and date palm flour. The low nutritional quality of cereals can be improved through supplementation with blends of defatted soya beans and carrot flour and date palm flours. Date palm has great 
effect on Ferrous reducing antioxidant property (FRAP), magnesium and zinc content of the flour. The addition of these flours had no improvement on the pasting property of the flour blends.

\section{References}

[1] O. O. Awolu and G. F. Oseyemi, "Physicochemical and rheological properties of optimised cocoyam-based composite flour comprising cassava starch," Acta Universitatis Cibiniensis. Series E: Food Technology, vol. 20, pp. 65-84, 2016. Available at: https://doi.org/10.1515/aucft-2016-0016.

[2] O. O. Awolu, "Optimization of the functional characteristics, pasting and rheological properties of pearl millet-based composite flour," Heliyon, vol. 3, pp. e00240-e00240, 2017. Available at: https://doi.org/10.1016/j.heliyon.2017.e00240.

[3] O. O. Awolu, "Rheological evaluation of cocoyam-bambara groundnut-xanthan gum composite flour obtained from the optimization of its chemical composition and functional properties," Rheology: Open Access, vol. 2, p. 118, 2018.

[4] Y. Bamigbola, O. Awolu, and I. Oluwalana, "The effect of plantain and tigernut flours substitution on the antioxidant, physicochemical and pasting properties of wheat-based composite flours," Cogent Food \& Agriculture, vol. 2, pp. 1-19, 2016 Available at: https://doi.org/10.1080/23311932.2016.1245060.

[5] O. O. Awolu, P. M. Oluwaferanmi, O. I. Fafowora, and G. F. Oseyemi, "Optimization of the extrusion process for the production of ready-to-eat snack from rice, cassava and kersting's groundnut composite flours," LWT-Food Science and Technology, vol. 64, pp. 18-24, 2015. Available at: https://doi.org/10.1016/j.lwt.2015.05.025.

[6] O. O. Awolu, R. O. Osemeke, and B. O. T. Ifesan, "Antioxidant, functional and rheological properties of optimized composite flour, consisting wheat and amaranth seed, brewers' spent grain and apple pomace," Journal of Food Science and Technology, vol. 53, pp. 1151-1163, 2016. Available at: https://doi.org/10.1007/s13197-015-2121-8.

[7] Food and Agriculture Organization / World Health Organization, "Obesity: Preventing and managing global epidemic," World Health Organization Technical Report, Geneva, Switzerland 1998.

[8] G. Ylimaki, Z. Hawrysh, R. Hardin, and A. Thomson, "Response surface methodology in the development of rice flour yeast breads: Sensory evaluation," Journal of Food Science, vol. 56, pp. 751-755, 1991. Available at: https://doi.org/10.1111/j.13652621.1991.tb05374.x.

[9] C. Klein, P. Chen, J. H. Arevalo, E. A. Stura, A. Marolewski, M. S. Warren, S. J. Benkovic, and I. A. Wilson, "Towards structure-based drug design: crystal structure of a multisubstrate adduct complex of glycinamide ribonucleotide transformylase at 1.96 A resolution," Journal of Molecular Biology, vol. 249, pp. 153-175, 1995 . Available at: https://doi.org/10.1006/jmbi.1995.0286.

[10] M. Riaz, "Healthy baking with soy ingredients," Cereal Foods World, vol. 44, pp. 136-139, 1999.

[11] P. M. Kotecha, B. B. Desai, and D. L. Madhavi, Carrot. In: Handbook of vegetable science and technology: Production, composition, storage, and processing. D. K. Salunkhe \& S. S. Kadam (Eds). New York: Marcel Dekker, Inc, 1998.

[12] F. Speizer, G. Colditz, D. Hunter, B. Rosner, and C. Hennekens, "Prospective study of smoking, antioxidant intake, and lung cancer in middle-aged women (USA)," Cancer Causes \& Control, vol. 10, pp. 475-482, 1999.

[13] A. I. Ihekoronye and P. O. Ngoddy. Integrated food science and technology for the tropics. London and Oxford: Macmillian Publishers Ltd. pp: 283-292, 1985.

[14] E. Shaba, M. Ndamitso, J. Mathew, M. Etsunyakpa, A. Tsado, and S. Muhammad, "Nutritional and anti-nutritional composition of date palm (Phoenix dactylifera L.) fruits sold in major markets of Minna Niger State, Nigeria," African Journal of Pure and Applied Chemistry, vol. 9, pp. 167-174, 2015. Available at: https://doi.org/10.5897/ajpac2015.0643.

[15] H. Gazalli, A. Malik, H. Jalal, S. Afshan, and A. Mir, "Proximate composition of carrot powder and apple pomace powder," International Journal of Food Nutrition and Safety, vol. 3, pp. 25-28, 2013.

[16] AOAC, Official methods of analysis of association of official analytical Chemist (AOAC) International. Method 960.39, method 950.46, method 920.153, method 992.15, 18th ed. Gaithersburg, MD, USA: AOAC, 2005.

[17] P. G. Waterman and S. Mole, Analysis of phenolic plant metabolites vol. 8. Oxford: Blackwell Scientific Publication, 1994.

[18] A. Meda, C. E. Lamien, M. Romito, J. Millogo, and O. G. Nacoulma, "Determination of the total phenolic, flavonoid and proline contents in Burkina Fasan honey, as well as their radical scavenging activity," Food Chemistry, vol. 91, pp. 571-577, 2005. Available at: https://doi.org/10.1016/j.foodchem.2004.10.006.

[19] J. M. Awika, L. W. Rooney, X. Wu, R. L. Prior, and L. Cisneros-Zevallos, "Screening methods to measure antioxidant activity of sorghum (Sorghum bicolor) and sorghum products," Journal of Agricultural and Food Chemistry, vol. 51, pp. 6657-6662, 2003. Available at: https://doi.org/10.1021/jfo34790i.

[20] M. Oyaizu, "Studies on products of browning reaction," The Japanese Journal of Nutrition and Dietetics, vol. 44, pp. 307-315, 1986. Available at: https://doi.org/10.5264/eiyogakuzashi.44.307.

[21] M. A. Gyamfi, M. Yonamine, and Y. Aniya, "Free-radical scavenging action of medicinal herbs from Ghana: Thonningia sanguinea on experimentally-induced liver injuries," General Pharmacology: The Vascular System, vol. 32, pp. 661-667, 1999. Available at: https://doi.org/10.1016/s0306-3623(98)00238-9.

[22] O. A. T. Ebuchi and A. C. Oyewale, "Effect of cooking and soaking on the physical characteristics, nutrient composition and sensory evaluation of indigeneous and foreign rice varieties in Nigeria," African Journal of Biotechnology, vol. 6, pp. 1016-1020, 2007.

[23] B. Bao and K. Chang, "Carrot pulp chemical composition, color, and water-holding capacity as affected by blanching," Journal of Food Science, vol. 59, pp. 1159-1161, 1994. Available at: https://doi.org/10.1111/j.1365-2621.1994.tb14666.x.

[24] J. W. Anderson, B. M. Smith, and N. J. Gustafson, "Health benefits and practical aspects of high-fiber diets," The American Journal of Clinical Nutrition, vol. 59, pp. 1242S-1247S, 1994. Available at: https://doi.org/10.1093/ajcn/59.5.1242s.

[25] F. J. He and G. A. MacGregor, "Beneficial effects of potassium," Bmj, vol. 323, pp. 497-501, 2001. Available at: https://doi.org/10.1136/bmj.323.7311.497.

[26] S. K. Arzoaquoi, E. E. Essuman, F. Y. Gbagbo, E. Y. Tenkorang, I. Soyiri, and A. K. Laar, "Motivations for food prohibitions during pregnancy and their enforcement mechanisms in a rural Ghanaian district," Journal of Ethnobiology and Ethnomedicine, vol. 11, p. 59, 2015. Available at: https://doi.org/10.1186/s13002-015-0044-0.

[27] L. Kass, J. Weekes, and L. Carpenter, "Effect of magnesium supplementation on blood pressure: A meta-analysis," European Journal of Clinical Nutrition, vol. 66, pp. 411-419, 2012. Available at: https://doi.org/10.1038/ejcn.2012.4.

[28] Y. Song, K. He, E. Levitan, J. Manson, and S. Liu, "Effects of oral magnesium supplementation on glycaemic control in type 2 diabetes: A meta-analysis of randomized double-blind controlled trials," Diabetic Medicine, vol. 23, pp. 1050-1056, 2006. Available at: https://doi.org/10.1111/j.1464-5491.2006.01852.x.

[29] J. Kaltenberg, L. M. Plum, J. L. Ober-Blöbaum, A. Hönscheid, L. Rink, and H. Haase, "Zinc signals promote IL-2-dependent proliferation of $\mathrm{T}$ cells," European Journal of Immunology, vol. 40, pp. 1496-1503, 2010. Available at: https://doi.org/10.1002/eji.200939574.

[30] K. Robards, P. D. Prenzler, G. Tucker, P. Swatsitang, and W. Glover, "Phenolic compounds and their role in oxidative processes in fruits," Food Chemistry, vol. 66, pp. 401-436, 1999. Available at: https://doi.org/10.1016/s0308-8146(99)00093-x.

[31] M. Viuda-Martos, Y. Ruiz-Navajas, A. Martin-Sánchez, E. Sánchez-Zapata, J. Fernández-López, E. Sendra, E. Sayas-Barberá, C. Navarro, and J. Pérez-Álvarez, "Chemical, physico-chemical and functional properties of pomegranate (Punica granatum L.) bagasses powder co-product," Journal of Food Engineering, vol. 110, pp. 220-224, 2012. Available at: https://doi.org/10.1016/j.jfoodeng.2011.05.029.

[32] I. Babic, M. Amiot, C. Nguyen-The, and S. Aubert, "Changes in phenolic content in fresh ready-to-use shredded carrots during storage," Journal of Food Science, vol. 58, pp. 351-356, 1993. Available at: https://doi.org/10.1111/j.1365-2621.1993.tb04273.x. S. L. Hansen, S. Purup, and L. P. Christensen, "Bioactivity of falcarinol and the influenceof processing and storage on its content in carrots (Daucus carota L)," Journal of the Science of Food and Agriculture, vol. 83, pp. 1010-1017, 2003. Available at: https://doi.org/10.1002/jsfa.1442. 
[34] U. Kidmose, S. L. Hansen, L. P. Christensen, M. Edelenbos, E. Larsen, and R. Nørbæk, "Effects of genotype, root size, storage, and processing on bioactive compounds in organically grown carrots (Daucus carota L.)," Journal of Food Science, vol. 69, pp. S388-S394, 2004. Available at: https://doi.org/10.1111/j.1365-2621.2004.tb09955.x.

[35] G. Block, "Nutrient sources of provitamin A carotenoids in the American diet," American Journal of Epidemiology, vol. 139, pp. 290-293, 1994. Available at: https://doi.org/10.1093/oxfordjournals.aje.a 116996.

[36] K. J. Lee, Y. C. Oh, W. K. Cho, and J. Y. Ma, "Antioxidant and anti-inflammatory activity determination of one hundred kinds of pure chemical compounds using offline and online screening HPLC assay," Evidence-Based Complementary and Alternative Medicine, vol. 15, p. 13, 2015. Available at: http://dx.doi.org/10.1155/2015/165457.

[37] P.-D. Duh and G.-C. Yen, "Antioxidative activity of three herbal water extracts," Food Chemistry, vol. 60, pp. 639-645, 1997. Available at: https://doi.org/10.1016/s0308-8146(97)00049-6.

[38] F. Biglari, A. F. AlKarkhi, and A. M. Easa, "Antioxidant activity and phenolic content of various date palm (Phoenix dactylifera) fruits from Iran," Food Chemistry, vol. 107, pp. 1636-1641, 2008. Available at: https://doi.org/10.1016/j.foodchem.2007.10.033.

[39] A. Panche, A. Diwan, and S. Chandra, "Flavonoids: An overview," Journal of Nutritional Science, vol. 5, pp. 1-15, 2016. Available at: https://doi.org/10.1017/jns.2016.41.

[40] S. Skrovánková, L. Mišurcová, and L. Machů, "Antioxidant activity and protecting health effects of common medicinal plants," Advances in Food and Nutrition Research, vol. 67, pp. 75-139, 2012. Available at: https://doi.org/10.1016/b978-0-12-3945983.00003-4.

[41] S. Chandra, S. Singh, and D. Kumari, "Evaluation of functional properties of composite flours and sensorial attributes of composite flour biscuits," Journal of Food Science and Technology, vol. 52, pp. 3681-3688, 2015.

[42] P. Kaushal, V. Kumar, and H. Sharma, "Comparative study of physicochemical, functional, antinutritional and pasting properties of taro (Colocasia esculenta), rice (Oryza sativa) flour, pigeonpea (Cajanus cajan) flour and their blends," LWT-Food Science and Technology, vol. 48, pp. 59-68, 2012. Available at: https://doi.org/10.1016/j.lwt.2012.02.028

[43] V. Abioye, B. Ade-Omowaye, and G. Babarinde, "Chemical, physico-chemical and sensory properties of soy-plantain flour," African Journal of Food Science, vol. 5, pp. 176-180, 2011.

[44] C. Mbofung, N. Y. Aboubakar, Y. Njintang, B. Abdou, and F. Balaam, "Physicochemical and functional properties of six varieties of taro (Colocasia esculenta L. Schott) flour," Journal of Food Technology, vol. 4, pp. 135-142, 2006.

[45] J. Tchoumboue, A. Niba, and A. Kenfack, "Comparative studies on the influence of supplementation with two legumes (Arachis glabrata and Desmodium intortum) on the reproductive and growth performance of guinea pigs (Cavia porcellus L.)," Bulletin of Animal Health and Production in Africa, vol. 49, pp. 79-83, 2001.

[46] M. Aremu, O. Olaofe, and E. Akintayo, "Functional properties of some Nigerian varieties of legume seed flours and flour concentration effect on foaming and gelation properties," Journal of Food Technology, vol. 5, pp. 109-115, 2007.

[47] M. Carcea and R. Acquistucci, "Isolation and physicochemical characterization of Fonio (Digitaria exilis Stapf) starch," StarchStärke, vol. 49, pp. 131-135, 1997. Available at: https://doi.org/10.1002/star.19970490403.

[48] E. Akintayo, A. Oshodi, and K. Esuoso, "Effects of $\mathrm{NaCl}$, ionic strength and $\mathrm{pH}$ on the foaming and gelation of pigeon pea (Cajanus cajan) protein concentrates," Food Chemistry, vol. 66, pp. 51-56, 1999. Available at: https://doi.org/10.1016/s03088146(98)00155-1.

[49] M. Kaur and N. Singh, "Studies on functional, thermal and pasting properties of flours from different chickpea (Cicer arietinum L.) cultivars," Food Chemistry, vol. 91, pp. 403-411, 2005. Available at: https://doi.org/10.1016/j.foodchem.2004.06.015.

[50] L. Emiola and L. Delarosa, "Physicochemical characteristics of yam starches," Journal of Food Biochemistry, vol. 5, pp. 115-130, 1981. Available at: https://doi.org/10.1111/j.1745-4514.1981.tbo0665.x.

[51] F. Dautant, K. Simancas, A. Sandoval, and A. Müller, "Effect of temperature, moisture and lipid content on the rheological properties of rice flour," Journal of Food Engineering, vol. 78, pp. 1159-1166, 2007. Available at: https://doi.org/10.1016/j.jfoodeng.2005.12.028.

[52] I. L. Batey and B. M. Curtin, "Effects on pasting viscosity of starch and flour from different operating conditions for the Rapid Visco Analyser," Cereal Chemistry, vol. 77, pp. 754-760, 2000. Available at: https://doi.org/10.1094/cchem.2000.77.6.754.

[53] C. Morris, G. King, and G. Rubenthaler, "Contribution of wheat flour fractions to peak hot paste viscosity," Cereal Chemistry, vol. 74, pp. 147-153, 1997. Available at: https://doi.org/10.1094/cchem.1997.74.2.147.

[54] B. Otegbayo, J. Aina, R. Asiedu, and M. Bokanga, "Pasting characteristics of fresh yams (Dioscorea spp.) as indicators of textural quality in a major food product-pounded yam," Food Chemistry, vol. 99, pp. 663-669, 2006. Available at: https://doi.org/10.1016/j.foodchem.2005.08.041.

[55] F. E. Ortega-Ojeda, H. Larsson, and A.-C. Eliasson, "Gel formation in mixtures of high amylopectin potato starch and potato starch," Carbohydrate Polymers, vol. 56, pp. 505-5 14, 2004. Available at: https://doi.org/10.1016/j.carbpol.2004.03.021. 